\title{
Методы количественного анализа гидролитической активности с использованием гелей с иммобилизованным субстратом
}

\author{
() И.А. Шпирная ${ }^{1}$, В.О. Цветков ${ }^{1}$, Н.Д. Рябцева ${ }^{2}$ \\ ${ }^{1}$ ФГБОУ ВО Башкирский государственный университет \\ Россия, Республика Башкортостан, 450076 г. Уфа, улица Заки Валиди, 32 \\ ${ }^{2}$ ФГБОУ ВО Башкирский государственный медицинский университет \\ Россия, Республика Башкортостан, 450008 е. Уфра, улица Ленина, 3 \\ E-mail: i-shia@yandex.ru
}

Сотрудниками кафедры биохимии и биотехнологии Башкирского государственного университета разработаны ряд относительно простых и удобных в применении методов количественного определения активности гидролитических фрерментов и их ингибиторов. Принцип методов заключается в иммобилизации субстрата фермента в гель агарозы или полиакриламидный гель (ПААГ) и последующем определении энзиматической активности: либо по размеру площади гидролиза субстрата вокруг лунок с ферментным раствором, либо по величине светопропускания через участки геля с субстратом. Показана применимость методов для определения активности протеиназ, карбогидраз, эстераз, а также ингибиторов этих ферментов в различных биологических объектах.

Ключевые слова: фрерменты, количественное определение, гель, цифровая обработка, модификация

Известно, что лабораторные исследования требуют использования разнообразных методик, которые не всегда могут быть реализованы, в первую очередь из-за недостаточности материально-технической базы.

В рамках своих исследований Ибрагимов Р.И. - заведующий (2000-2017 гг.) кафедрой биохимии и биотехнологии Башкирского государственного университета (г. Уфа) разрабатывал оригинальные и доступные методы для решения поставленных задач [1].

И в настоящее время одним из направлений, которое активно развивается на кафедре биохимии и биотехнологии, является разработка и модификация методов детекции ферментативной активности, начало которым положили работы Рината Исмагиловича.

Ибрагимовым Р.И. были разработаны методы определения активности свободных и «связанных» ингибиторов протеаз, находящихся в составе комплекса с ферментом [2], был предложен метод количественного определения протеолитических ферментов и их ингибиторов с использованием фотопластин [3].

Суть предложенного им метода состояла в использовании специальных фотопластинок для ядерных исследований. Поверхность пластины со стороны желатинового слоя покрывалась агарозным гелем. В геле вырезали лунки, которые заполняли раствором фрермента. Пластинки выдерживали заданное время во влажной камере. Молекулы фрермента из раствора дифффундируют в гель и гидролизуют желатину (субстрат) вокруг лунки (рис.1). Скорость диффрузии молекул в геле пропорциональна исходной кон- 
центрации фермента в растворе. После окончания инкубации агарозный гель снимают, пластину промывают водой. Гидролизованные участки желатинового покрытия хорошо смываются и проявляются на темном фроне в виде светлых участков округлой фрормы. Определение ферментативной активности проводится путем измерения интенсивности светового потока, проходящего через гидролизованный участок желатина. Для этой цели был разработан и сконструирован прибор, позволяющий измерять интенсивность света, проходящего через пластину. Это устройство состоит из источника света, фотоприемника и измерительного прибора. Для проведения замеров фотопластинка помещается между источником света и фотоприемником устройства. Активность фрермента определяется по интенсивности светового потока, проходящего через гидролизованные участки желатинового слоя фротопластинки [3].

Метод позволяет обнаружить и измерить активность желатингидролизующих протеиназ и их ингибиторов из различных источников, характеризуется высокой чувствительностью. По сравнению со спектрофотометрическими методами, в описанной процедуре используются микрообъемы ферментных растворов (5-10 мкл), что снижает расход препаратов в несколько десятков раз.

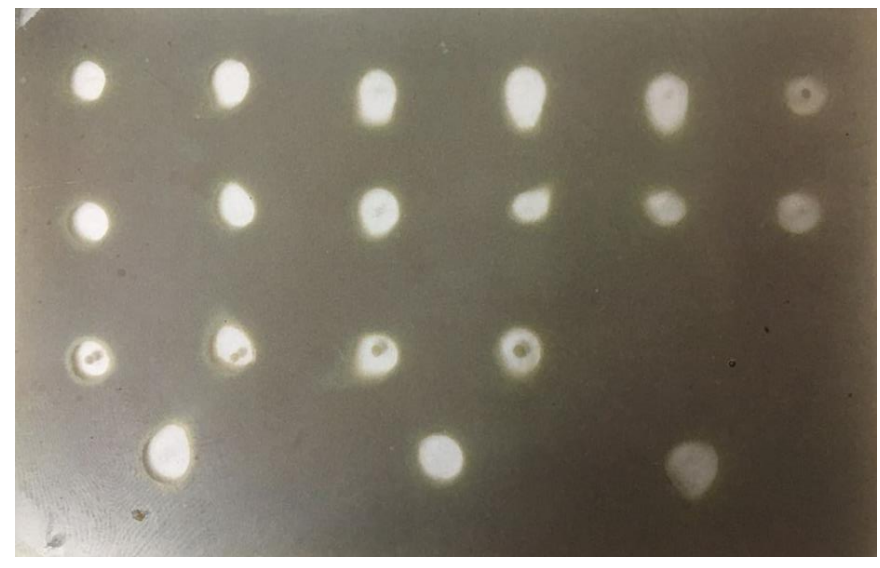

Рис.1. Фотопластинка после инкубации с растворами ферментов (видны округлые зоны гидролиза желатинового слоя).

Дальнейшие работы в этом направлении привели к существенному расширению спектра анализируемых ферментов за счет включения различных субстратов в $1 \%$ гель агарозы. Благодаря этому студенты и аспиранты кафедры биохимии и биотехнологии стали активно проводить эксперименты по определению активности различных протеиназ (рис.2), карбогидраз, эстераз. Данные методики подробно описаны в работах [4-8]. Все преимущества метода-прототипа при этом сохранялись, однако широкое использование методов ограничивалось дороговизной высоокоочищенной агарозы, поскольку только такая фрорма образовывала стабильные гели без деформации лунок и позволяла получать валидные результаты анализа. 


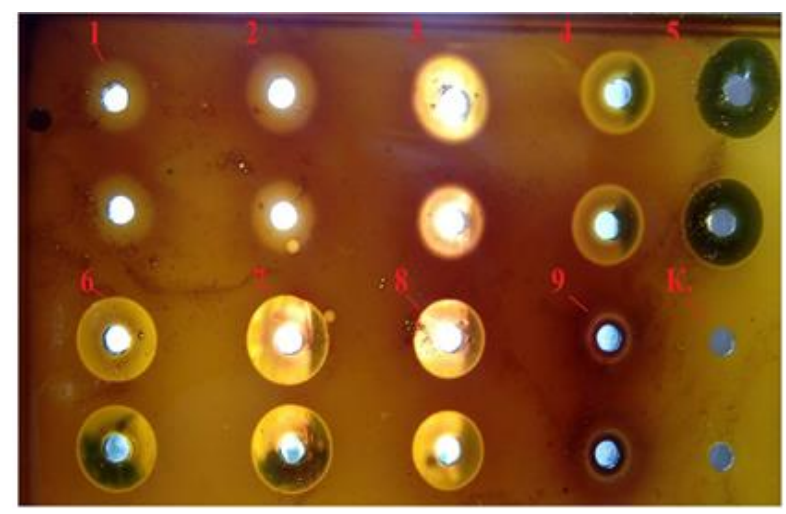

Рис.2. Агарозная пластина с иммобилизованным казеином после инкубации с экстрактами плодовых тел трутовиков (источник фрерментов) и окраски бромфеноловым синим.

Попытки заменить агарозу на более дешевые субстраты привели к существенной модификации метода. Метод с применением полиакриламидного геля позволил значительно сократить время и снизить расход реактивов для определения ферментативной активности, однако использование ПААГ было возможным только при отсутствии в нем лунок для заливки раствора (Рис.3). Изыскания в этом направлении привели к разработке принципиально иного технического исполнения, подробно описанного в работах [9-11].

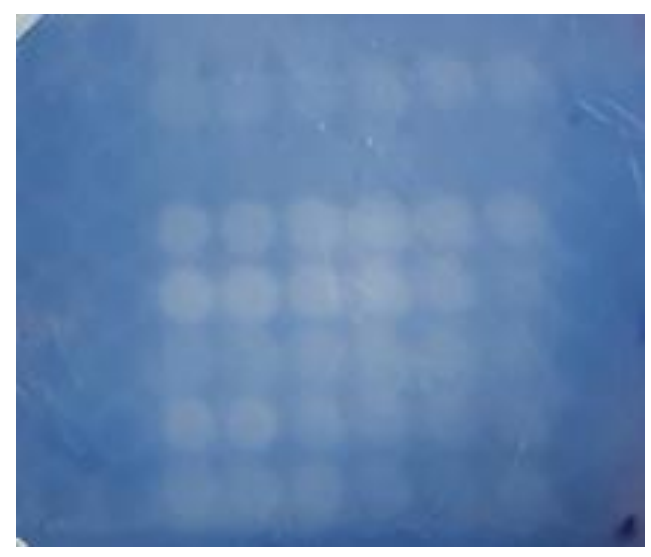

Рис. 3. ПААГ с иммобилизованным крахмалом после инкубации с растворамиисточниками амилолитической активности

Доступность цифровой техники позволила обрабатывать изображения гелей для количественного определения фрерментативной активности (Рис. 4 а,б). Были разработаны программные инструменты для количественного определения уровня активности ферментов и их ингибиторов на основе анализа оцифрованных гелей [12-16]. 


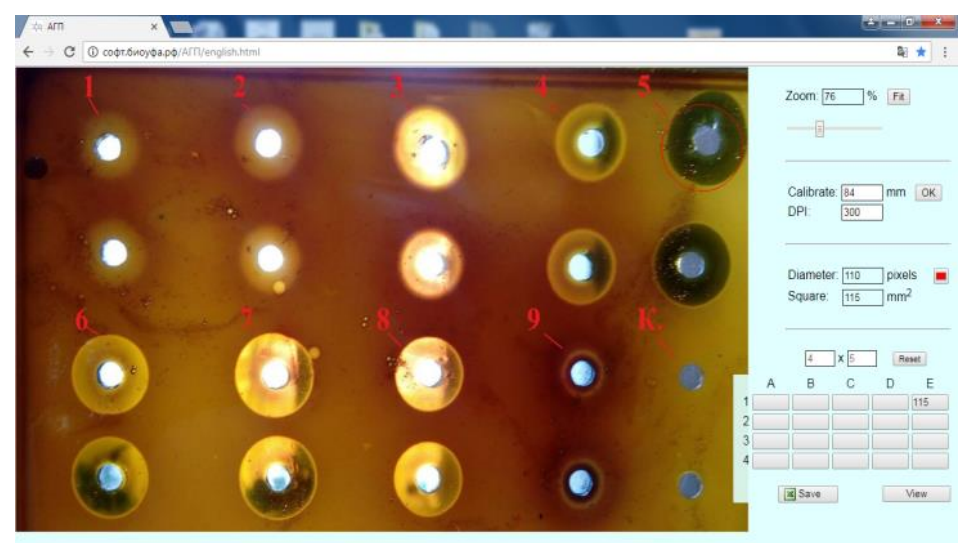

(A)

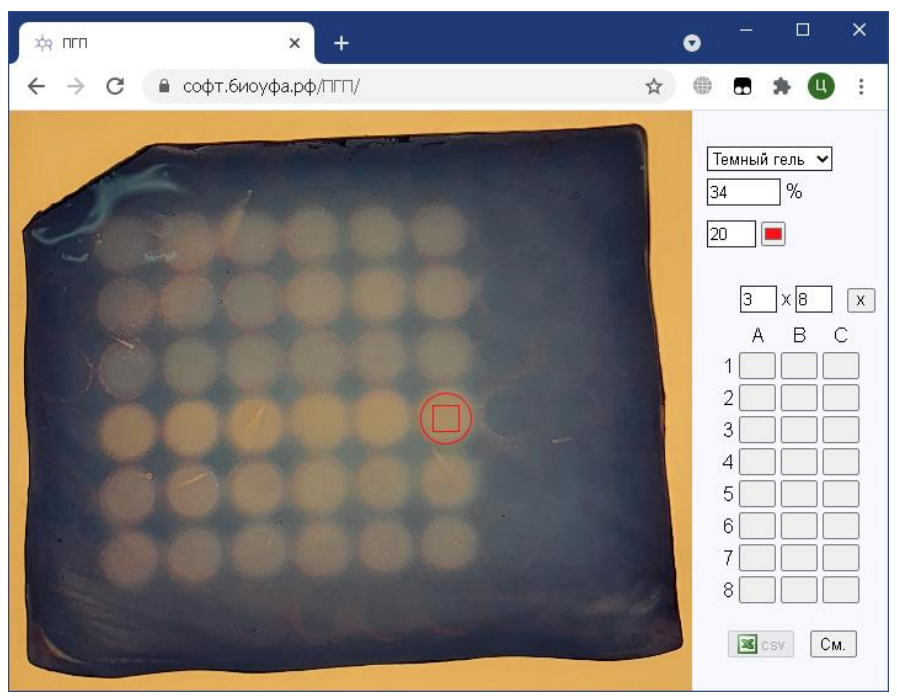

(Б)

Рис.4. (A) Компьютерная программа для расчета площади гидролизованного участка агарозной пластины https://софтт.биоуфа.pф/АГП/ (Б) Компьютерная программа для расчета площади гидролизованного участка ПААГ https://софтт.биоуфа.pф/ПГП/

Использование данных методов лежит в основе многочисленных дипломных проектов студентов кафедры биохимии и биотехнологии, используется при выполнении кандидатских диссертаций.

\section{Литература}

1. Шпирная И.А., Фархутдинов Р.Г. , Яруллина Л.Г. , Марданшин И.С. , Цветков В.О. Памяти профессора Ибраимова Рината Исмагиловича - к 65-летию со дня рождения // Биомика. 2021. №2. С. 227-243.

2. Ибрагимов Р.И., Яковлев В.Г., Ахметов Р.Р. Определение активности ингибиторов в составе комплекса с протеиназой // Физиология и биохимия культурных растений. 1987. № 1. С. 51-54. 
3. Ибрагимов Р.И., Ахметов Р.Р., Хабибуллин С.И. Способ определения активности протеолитических фрерментов. Патент на изобретение RU 2175134 C1. 20.10.2001.

4. Шпирная И.А., Умаров И.А., Шевченко Н.Д., Ибрагимов Р.И. Определение активности гидролаз и их ингибиторов по гидролизу субстрата в геле агарозы // Прикладная биохимия и микробиология. 2009. Т.45(4). С.497-501.

5. Шевченко Н.Д., Шпирная И.А., Ибрагимов Р.И. Метод измерения активности пектиназ по гидролизу иммобилизованного субстрата // Аграрная Россия. 2009. № S1. C. 133-134.

6. Шевченко Н.Д., Ибрагимов Р.И., Шпирная И.А., Умаров И.А., Хамадалиев Р.Ф. Активность компонентов системы "эстеразы - ингибиторы эстераз колорадского жука" в тканях картофеля // Вестник Башкирского университета. 2008. Т. 13. № 4. С. 922-925.

7. Шевченко Н.Д., Шпирная И.А., Саляхова А.Ф., Цветков В.О., Марданшин И.С., Ибрагимов Р.И. Активность ингибиторов целлюлаз, пектиназ в клубнях и листьях картофреля // Вестник Оренбургского государственного университета. 2009. № 6 (100). С. 431-433.

8. Шляпникова С.В., Батырова Э.Р., Цветков В.О., Шпирная И.А. Изучение молокосвертывающей активности фрерментов трутовых грибов // Известия Уфимского научного центра РАН. 2017. № 3-1. С. 228-232.

9. Ц Цветков В.О., Шпирная И.А., Максутова В.О. Способ количественного определения протеолитической активности ферментов по гидролизу субстрата, иммобилизованного в полиакриламидном геле. Патент на изобретение RU 2701734 C1. 01.10.2019.

10. Цветков В.О., Шпирная И.А., Максутова В.О. Способ количественного определения амилолитической активности ферментов по гидролизу субстрата, иммобилизованного в полиакриламидном геле. Патент на изобретение RU 2708087 C2. 04.12.2019.

11. Цветков В.О., Шпирная И.А., Максутова В.О., Ибрагимов Р.И. Определение активности амилаз и протеаз с использованием субстратов, иммобилизованных в поликриламидном геле // Известия Уфимского научного центра Российской академии наук. 2018. № 3-5. С. 81-85.

12. Ибрагимов Р.И., Фазлытдинов М.Ф., Цветков В.О., Шпирная И.А. Инструмент количественной оценки активности амилолитических ферментов и ингибиторов амилаз по площади зоны гидролизованного крахмала, иммобилизованного в гель агарозы. Свидетельство о регистрации программы для ЭBM RU 2015612790. 26.02.2015.

13. Ибрагимов Р.И., Цветков В.О., Шпирная И.А. Инструмент определения фрерментативной активности по интенсивности пятен на зимограммах. Свидетельство о регистрации программы для ЭBM RU 2015661375. 26.10.2015.

14. Фазлытдинов М.Ф., Шпирная И.А., Цветков В.О., Ибрагимов Р.И., Умаров И.А. Программа для измерения активности пектиназ и их ингибиторов на пластинах агарозного геля. Свидетельство о регистрации программы для ЭВМ № 20120610010 1. 10.01.2012

15. Цветков В.О., Шпирная И.А., Ибрагимов Р.И. Сервис просмотра и анализа структуры биомолекул. Свидетельство о регистрации программы для ЭВM RU 2016615885, 01.06.2016. Заявка № 2016612978 от 04.04.2016. 
16. Цветков В.О., Шпирная И.А., Максутова В.О. Инструмент определения гидролитической активности по гидролизу субстрата в полиакриламидном геле. Свидетельство о регистрации программы для ЭBM RU 2018611900. 08.02.2018.

\section{Methods of quantitative analysis of hydrolytic activity using gels with an immobilized substrate}

Employees of the Department of Biochemistry and Biotechnology of Bashkir State University have developed a number of relatively simple and easy-to-use methods for quantifying the activity of hydrolytic enzymes and their inhibitors. The principle of the methods is to immobilize the enzyme substrate in agarose gel or polyacrylamide gel (PAAG) and then determine the enzymatic activity: either by the size of the substrate hydrolysis area around the wells with the enzyme solution, or by the amount of light transmission through the gel sections with the substrate. The applicability of methods for determining the activity of proteinases, carbohydraz, esterases, as well as inhibitors of these enzymes in various biological objects is shown.

Keywords: enzymes, quantitative determination, gel, digital processing, modification 